Biocontrol Science, 1996, Vol. 1, No. 1, 61-63

$\overline{\text { Note }}$

\title{
Use of a Tumbling-Defective Mutant of Escherichia coli for Evaluation of Pollutant Toxicity by Computer-Assisted Image Analysis of Bacterial Motion
}

\author{
TETSUAKI TSUCHIDO'* , KENJI YASUNAGA', YOSHINOBU MATSUMURA', \\ AND KIYOHARU OKU² \\ ${ }^{1}$ Department of Biotechnology, Faculty of Engineering, Kansai University, Suita 564, Japan, \\ and ${ }^{2}$ Keio Electronic Ind. Co., Ltd., Funaki-cho, Ibaraki 567, Japan
}

Received 25 March 1996/Accepted 10 April 1996

\begin{abstract}
For the evaluation of pollutant toxicity in the aquatic environment, a novel principle of a dynamic image analysis of bacterial motion by using a tumbling-ability-defective mutant of Escherichia coli $\mathrm{K}-12$, OW22, isolated as a laboratory indicator organism, is proposed. The average linear motion speed of intact cells of this mutant was approximately $32 \mu \mathrm{m} / \mathrm{s}$ and decreased markedly by the presence of model chemical pollutants tested. It was suggested that the mutant should be useful as an indicator organism for the evaluation of pollutant toxicity by the dynamic image analysis method.
\end{abstract}

Key words : Escherichia coli/Tumbling-defective mutant/Pollutant toxicity/Image analysis/Bacterial motion.

Motile bacterial cells move by rotating their flagella and demonstrate taxis (Macnab, 1987; Khan, 1990). In general, depending upon the direction of flagellum rotation, a cell exhibits two modes of movement, i.e. linear swimming and tumbling, in the case of many kinds of bacteria including $E$. coli. Cells require proton motive force as an energy source for both modes of movement. If a cell is exposed to the stress of pollution in its aquatic environment, it should become less motile or non-motile due to the reduction or depletion of its energy level. Based upon this principle, the measurement of bacterial motility should be useful for rapid monitoring of water pollution, although other biomonitoring methods have been proposed (Loeb and Spacie, 1994).

By using a dynamic image analysis system consisting of a motion analyzer and a microscope, we have already reported the motion characteristics of stressed cells of a wild-type Bacillus subtilis 168 and its possible application to the evaluation of bacterial

${ }^{*}$ Corresponding author. Tel. : +81-6-368-0880, Fax : +816-388-8609. injury' (Tsuchido et al., 1994). However, this preliminary system had two practical problems in the evaluation of injury: first, tumbling gave rise to a great variation of cellular motion speed; second, its motility was rapidly reduced during the observation period due to the aerobic property of indicator organism tested, B. subtilis (Tsuchido, 1993; Tsuchido et al., 1994).

In this study, therefore, we switched to the use of $E$. coli, which is a facultatively anaerobic bacterium and also a general hygienic indicator bacterium for assessing microbial contamination levels in the food industry and the pollution of aquatic environments. In addition, we attempted to isolate its tumblingdefective mutant to discriminate the loss of motility caused by exposure to a chemical pollutant from the tumbling as a normal mode of motion. The purpose of this study is to analyze the motion of the cells of this mutant exposed to chemical pollutants and further propose the principle of a novel bioassay method for the evaluation of aquatic pollution.

Several tumbling-defective. mutants of $E$. coli were isolated as described previously (Parkinson, 1976). 
The cell suspension of wild type OW6 strain (pro) (Miyake et al., 1993) was spread on the swarm agar plates of $L$ broth consisting of $10 \mathrm{~g}$ tryptone (Difco), $5 \mathrm{~g}$ yeast extract (Difco), $5 \mathrm{~g} \mathrm{NaCl}$ and $4 \mathrm{~g}$ agar powder per $1 \mathrm{I}$ of distilled water supplemented with $0.2 \%$ $(\mathrm{w} / \mathrm{v})$ glucose. The plates were exposed to UV light and then incubated at $37^{\circ} \mathrm{C}$. The relatively large resultant colonies were picked up. Several tumblingdefective strains were selected from those colonies by observation under a microscope (Olympus, $\mathrm{BH} 2$ ) and one of those was designated OW22 and employed in this study.

An overnight culture of OW22 strain was inoculated into a $100-\mathrm{ml}$ flask containing $20 \mathrm{ml}$ of $\mathrm{L}$ broth. The flask was then shaken at $37^{\circ} \mathrm{C}$ at a speed of $80 \mathrm{rev} /$ min. When the OD at a wavelength of $650 \mathrm{~nm}(\mathrm{O}$ $\mathrm{D}_{650}$ ) of the culture reached 0.3 , potassium cyanide or cetyltrimethylammonium bromide (CTAB), as a model pollutant, was added. Both compounds were purchased from Wako Pure Chemical Co.

A sample. $(1 \mathrm{ml})$ was withdrawn and poured into a test tube $(16 \mathrm{~mm} \times 160 \mathrm{~mm})$ and Tween 80 was added to this tube at a final concentration of $0.01 \%$ to avoid cell adsorption to the glass coverslips described below. A portion $(4 \mu \mathrm{I})$ was withdrawn from the cell suspension, immediately placed on a glass slide prewarmed at $37^{\circ} \mathrm{C}$, and overlaid with a cover-slip (1 $8 \mathrm{~mm} \times 18 \mathrm{~mm})$. The edges were then sealed with manicure paste.

Microscopy and image analysis of cell motion were performed as described previously (Tsuchido et al., 1994). The above preparation was mounted on the stage of a phase contrast microscope ( $\mathrm{BH}-2$, Olympus, 12V 100W HAL-L). A heat reflection filter was used to avoid an increase in temperature during the observation period. An NEC CCD camera ( $\mathrm{Tl}$ 23A) was attached to the microscope by means of a spacing adapter (Olympus, MTV-3) and connected

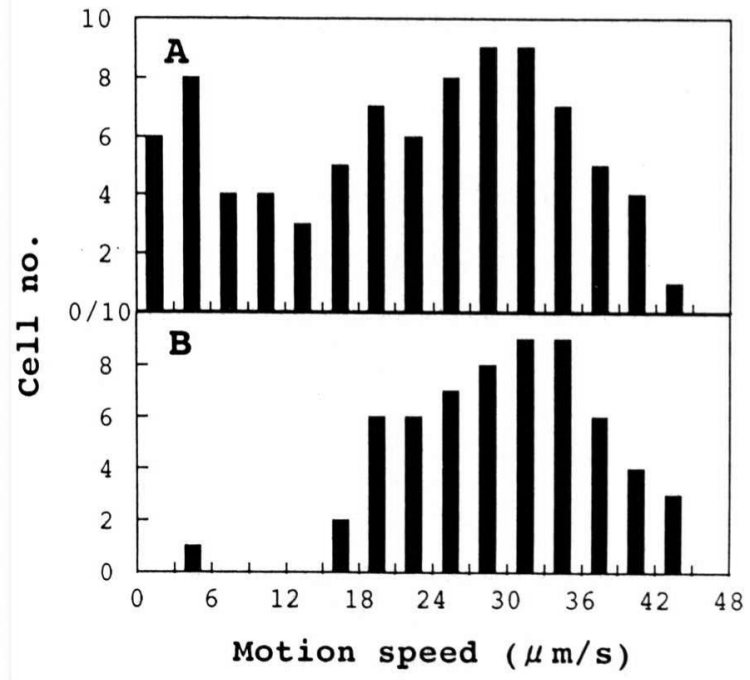

FIG. 1. Histograms of the distribution of the average linear motion speed of cells of a wild-type OW6 strain (A) and a tumbling-defective OW22 mutant (B). The total numbers of observed cells were 81 and 54 , respectively.

directly to a Keio Motion Analysis System (MD-20R, Keio Electronic Ind. Co. Ltd., Ibaraki, Osaka). Images were digitized in real-time at 20 frames/s (0.05-s intervals during a 1-s period) and were detected and analyzed on a personal computer (NEC, PC9801) by a motion analysis program, MAS version 1.22 (Keio Electronic Ind.). Image areas of dark bacterial cells on a light background were processed by the analyzer and recorded on a grid of 241 vertical by 256 horizontal pixels $(6.25$ pixels $/ \mu \mathrm{m})$. A total of 8 to 15 scenes, each containing one to five cells, were imageprocessed.

The motion speed of all of the cells killed by heat treatment at $90^{\circ} \mathrm{C}$ for $10 \mathrm{~min}$ was below $6.0 \mu \mathrm{m} / \mathrm{s}$, and thus regarded to the maximum Brownian motion level. A normal distribution of the motion speed was obtained for a population of motile cells growing in the

TABLE 1. Effects of CTAB and potassium cyanide on the motility of E. coli OW22 strain

\begin{tabular}{cccc}
\hline $\begin{array}{c}\text { Concn } \\
(\mu \mathrm{M})\end{array}$ & $\begin{array}{c}\text { Observed } \\
\text { cell no. }\end{array}$ & $\begin{array}{c}\text { Avg motion speed } \\
\pm \text { S.D. }(\mu \mathrm{m} / \mathrm{s})\end{array}$ & $\begin{array}{c}\text { Percentage of motile } \\
\text { cells }(\%)\end{array}$ \\
\hline CTAB & & & \\
0 & 46 & $31.8 \pm 6.2(100)^{a}$ & 95 \\
2 & 44 & $25.6 \pm 6.7(81)$ & 91 \\
4 & 40 & $21.2 \pm 6.4(67)$ & 88 \\
6 & 36 & $19.6 \pm 5.4(62)$ & 86 \\
8 & 31 & $13.4 \pm 5.1(42)$ & 68 \\
Potassium cyanide & & & \\
0 & 50 & $30.0 \pm 6.6(100)$ & 96 \\
10 & 36 & $21.5 \pm 6.3(49)$ & 67 \\
100 & 31 & $13.8 \pm 5.6(37)$ & 58 \\
\hline
\end{tabular}

${ }^{a}$ percentage. 
medium at $37^{\circ} \mathrm{C}$ (Fig. 1). On the contrary to the wildtype OW6 strain, there were only few cells showing a motion speed of less than $6.0 \mathrm{\mu m} / \mathrm{s}$ in OW22 strain. In the representative data (Fig. 1), the average motion speed of motile cells was $32.3 \pm 7.8 \mu \mathrm{m} / \mathrm{s}$ (S.D.), whereas that of the wild type OW6 was 27.2 $\pm 9.4 \mathrm{\mu m} / \mathrm{s}$ (S.D.). These average values varied from experiment to experiment in ranges from 31 to $33 \mu \mathrm{m} / \mathrm{s}$ and from 27 to $29 \mu \mathrm{m} / \mathrm{s}$, respectively.

We analyzed the motility of cells of OW22 mutant exposed to a surface active agent, CTAB, and potassium cyanide as model chemical pollutants. Increasing concentrations of CTAB and potassium cyanide caused a marked reduction in the average motion speed of the cells that was accompanied by a decreased percentage of motile cells (Table 1).

An apparently high motion speed of OW22 mutant and an extraordinary high percentage of motile cells were substantially due to the non-tumbling property of this strain and thus the reduction in the motion speed as well as in the percentage of motile cells can be considered to correspond directly to the degree of pollution stress experienced by. the cell population. OW22 strain was therefore suggested to be an excellent indicator bacterium for the aquatic pollution bioassay. The reduction in motion speed may reflect the lowering of the cellular energy level, although the possibility of the release of flagella from the cell during the encounter with a pollutant cannot be ruled out.

We have already suggested that this image analysis system of cell motion can be applied to the rapid and simple evaluation of bacterial injury for microbiological control in food, pharmaceutical, and fermentation industries (Tsuchido et al., 1994). An additional case of application to the efficacy evaluation of antimicrobial compounds is presented elsewhere (Tsuchido et al., 1996). We further propose here that the principle of this system can be applied to the biological monitoring of chemical pollution as a novel, efficient and rapid method. The study of the practical use of this method for biomonitoring is under investigation.

\section{ACKNOWLEDGMENT}

This study was supported by a grant from the Bioscience Research Program of the Research Institute of Industrial Technology, Kansai University.

\section{REFERENCES}

Khan, S. (1990) Motility. In The Bacteria. 12. Bacterial Energetics (Krulwich, T. A., ed.), pp. 301-343, Academic Press Inc., New York.

Loeb, S. L., and Spacie, A. (1994) Biological Monitoring of Aquatic Systems. Lewis Publishers, Boca Raton.

Macnab, R. M. (1987). Motility and chemotaxis. In Escherichia coli and Salmonella typhimurium. Cellular and Molecular Biology (Neidhardt, F. C., Ingrahan, J. L., Low, K. B., Magasanik, B., Schaechter, M., and Umbarger, H. E., ed.), pp. 732759, American Society for Microbiology, Washington, D. C.

Miyake, T., Araki, S., and Tsuchido, T. (1993) Synthesis and sedimentation of a subset of $15-\mathrm{kDa}$ heat shock proteins in Escherichia coli cells recovering from sublethal heat stress. Biosci. Biotechnol. Biochem., 57, 578-583.

Parkinson, J. S. (1976) che A, cheB, and cheC genes of Escherichia coli and their role in chemotaxis. J. Bacteriol., 126, 758-770.

Tsuchido, T. (1993) Image analysis of bacterial motility and its application to the evaluation of cell activity and viability (in Japanese). Rep. Biosci. Res. Kansai Univ., pp. 33-43.

Tsuchido, T., Takeuchi, H., Kawahara, H., and Obata, H. (1994) Evaluation of bacterial injury by image analysis of cell motion. J. Ferment. Bioeng., 78, 185-187.

Tsuchido, T., Yasunaga, K., Matsumura, Y., and Oku, K. (1996) Efficacy evaluation of antimicrobial compounds by dynamic image analysis of bacterial motion. Proc. 10th Int. Symp. Biodeterioration Biodegradation, pp. 45-50. 